\title{
Behavioral and Living Environmental Factors Associated with Dengue Haemorrhagic Fever Prevalence in Air Dingin Public Health Center, Padang City
}

\section{Masrizal, Ira Wiratni, and Onetusfifsi Putra}

Faculty of Public Health, Andalas University, Padang, Indonesia

\section{Abstract}

Dengue Hemorrhagic Fever (DHF) is a major public health problem in Indonesia. An Incidence Rate (IR) of 361/100.000 population was accounted at Air Dingin. The purpose of this study was to know the relationship between living environment and $3 \mathrm{M}$ Plus behavior with DHF prevalence in Air Dingin. A case-control study with simple random sampling was conducted at Air Dingin Public Health Center from December to June 2016. The samples were divided into two groups of case and control groups of 39

Corresponding Author:

Masrizal

masrizal_khaidir@yahoo.com

Received: 26 December 2018 Accepted: 23 February 2019 Published: 7 March 2019

Publishing services provided by Knowledge E

(c) Masrizal et al. This article is distributed under the terms of the Creative Commons

Attribution License, which permits unrestricted use and redistribution provided that the original author and source are credited.

Selection and Peer-review under the responsibility of the $2 \mathrm{nd}$ International Meeting of Public Health 2016 Conference Committee. while controlling the age and domicile. The obtained data was then analyzed using univariate, bivariate, and multivariate analysis. Bivariate analysis results showed : the house temperature $p$-value $=0.065$; humidity houses $p$-value $=0.687$; light $p$-value $=0.002$; density residential home $p$-value $=0.359$; drain water reservoirs $p$-value $=$ 0.359 ; close water reservoirs $p$-value $=0.179$; buy thrift $p$-value $=0.002$; insect screen use $p$-value $=0.179$; and hanging clothes behavior $p$-value $=0.014$. Multivariate analysis result showed that the dominant factor was the lighting ( $p$-value=0.029 OR=3.34). Three variables had significant relationship with DHF prevalence : lighting, waste products burying/disposing behavior and hanging clothes behavior.

Keywords: DBD; environment home; practice 3M Plus

\section{Introduction}

Dengue Hemorrhagic Fever (DHF) or Dengue Hemorrhagic Fever (DHF) is commonly found in the tropics and sub-tropics area. The global data showed that Asia ranks first in the number of DHF patients annually. Meanwhile, from 1968 until 2009, the World Health Organization (WHO) noted that Indonesia has the highest DHF cases in Southeast Asia (Kemenkes 2010). DHF is a significant public health problem tha considered as an endemic disease that not only often leading to outbreak but increasing the death rate (Kemenkes RI 2010). The spread of dengue disease is increasing in line with the high population growth, unplanned and uncontrolled urbanization, lack of effective mosquito vector control in endemic areas, and transportation improvements (Kemenkes RI 2004). 
Padang city consists of 11 districts with 22 health centers within. Among the 22 health centers, health centers Air Dinginhas the nhighest cases of Dengue Feve. The prevalence of cases was increased significantly in 2015 compared to 2014 and 2013 prevalence. In 2013 Incidence Rate (IR) of DHF in Air Dingin Public Health Center (PHC) was accounted to be $177.95 / 100,000$ population, then it was dropped in 2014 to be $80.8 / 100,000$ people, and further significant increase in 2015 with IR 361.5/ 100,000 population (Dinkes RI 2014).

The occurrence of DHF is caused by the interaction between the agent, host, and environmental factors. Environmental factors are very decisive in the contact between the host and agent. Housing conditions and environments that do not meet the basic health requirements are the major risk factors transmission source of various diseases, especially environment-linked diseases, including DHF (Winarsih 2013). Living environment factors that affect the DHF prevalence include air temperature, humidity, lighting, and the dwelling density.

Temperature is closely linked with the mosquitos' life cycle and directly influence the development of the parasite in the vector's body. The optimum temperature for vector breeding range between $25-27^{\circ} \mathrm{C}$. Humidity affects the lifespan of mosquitoes, humidity $<60 \%$ results in a short mosquitoes lifespan ((Kemenkes 2012). of the climate in Padang is very supportive for the mosquitoes' life cycle because the average temperature of Padang in 2014 was $22.2^{\circ} \mathrm{C}-31.6^{\circ} \mathrm{C}$ with the humidity ranged from 80-85\% (Dinkes RI 2014).

In mosquitos' life cycle there are three necessary thing that are highly need for the survival:breeding place, food source and resting place. Vector control programs in Indonesia is the mosquito nest eradication (Pemberantasan Sarang Nyamuk/ PSN) through 3M Plus behavior (Menguras, menutup, mengubur/ drain water reservoirs, close the water reservoirs, bury the waste products and other supplemented means) (Sumantri 2010; Kemenkes RI 2011). 2014Padang city health Report stated that the percentage of domestic coverage $t$ mosquito larvae eradication in the Air Dingin Health Center was $61.3 \%$. This achievement was still low when compared to the target $(80 \%)$ and Figures indicator Free Flick goal ( $\geq$ 95\%) (Dinkes RI 2014).

Based on the above facts and data, the researchers were interested in researching "Relations Home Environment and Practice 3 M Plus with Genesis Dengue Hemorrhagic Fever at public health of Air Dingin in the Padang city 2016". 


\section{Methods}

This is an observational analytic research with case-control study. This study was conducted at the Air Dingin PHC, in December to June 2016.

The samples in the case group weres all the people who had been diagnosed with DHF in 2015 at the Air Dingin PHC and recorded in the medical records. Control samples were patients of the Air Dingin PHC that never diagnosed with dDHF in 2015. The sample size in this study were 36 samples, to anticipate the drop out, $10 \%$ of the samples were added. Hence the number of samples were 39 as the case group and 39 control group, with a total of 78 samples. The sampling technique used in this study was simple random sampling using a random table while controlling the age and residence.

The collected data consist of primary and secondary data. The data then processed through editing, coding, entry, and cleaning. The analysis of data using univariate, bivariate and multivariate analysis with Mc Nemar statistical tests, with a 95\% confidence level $(\alpha=0.05)$ and logistic regression.

\section{Results}

\subsection{Univariate analysis}

Table 1 shows the frequency distribution of each independent variable based on the case group and the control group. The percentages of respondents with the suitable temperature for the dengue disease transmission $\left(\geq 32-35^{\circ} \mathrm{C}\right.$ ) was more in the case group (46.15\%) compared to the control group (30.77\%). The percentages of respondents with suitable air humidity mosquitoes' life cycle $(\geq 60 \%)$ was more prevalent in the case group (89.74\%) compared to the control group (87.18\%). The percentages of respondents who had dark house lighting were more prevalent in the case group (61.54\%) compared to the control group (23.08\%). The rates of respondents who lived in the more crowded housing was more abundant in the control group (23.08\%) compared with the case group (33.33\%). The proportion of respondents who drain their water reservoir more than once a week was more prevalent in the case group (33.33\%) compared with the control group (23.08\%). The proportion of respondents who did not cover their water reservoirs is more prevalent in the case group (17.95\%) compared with the control group (7.69\%). The proportion of respondents who rarely bury / dispose the used goods was more prevalent in the case group (79.49\%) compared with the control group (46.15\%). The percentages of respondents did not use the insect screen is more prevalent in the case group (89.74\%) compared with the control group (76.92\%). The proportion of respondents who hang 
TABLE 1: Frequency Distribution of Respondents by Independent Variables.

\begin{tabular}{|c|c|c|c|c|c|c|}
\hline \multirow[t]{2}{*}{ Variables } & \multicolumn{2}{|c|}{ Case } & \multicolumn{2}{|c|}{ Control } & \multicolumn{2}{|c|}{ Total } \\
\hline & $f$ & $\%$ & $f$ & $\%$ & $\mathbf{n}$ & $\%$ \\
\hline \multicolumn{7}{|l|}{ Temperature } \\
\hline Good $\left(\geq 32-35^{\circ} \mathrm{C}\right)$ & 18 & 46.15 & 12 & 30.77 & 30 & 38.46 \\
\hline $\begin{array}{l}\text { Not good }\left(<32^{\circ} \text { or }\right. \\
\left.>35^{\circ} \mathrm{C}\right)\end{array}$ & 21 & 53.85 & 27 & 69.23 & 48 & 61.54 \\
\hline Total & 39 & 100 & 39 & 100 & 78 & 100 \\
\hline \multicolumn{7}{|l|}{ Humidity } \\
\hline Good ( $\geq 60 \%)$ & 35 & 89.74 & 34 & 87.18 & 69 & 88.46 \\
\hline Not good (<60\%) & 4 & 10.26 & 5 & 12.82 & 9 & 11.54 \\
\hline Total & 39 & 100 & 39 & 100 & 78 & 100 \\
\hline \multicolumn{7}{|l|}{ The lighting } \\
\hline Dark & 24 & 61.54 & 9 & 23.08 & 33 & 42.31 \\
\hline Not Dark & 15 & 38.46 & 30 & 76.92 & 45 & 57.69 \\
\hline Total & 39 & 100 & 39 & 100 & 78 & 100 \\
\hline \multicolumn{7}{|l|}{ The density of room } \\
\hline Dense & 9 & 23.08 & 13 & 33.33 & 22 & 28.21 \\
\hline Not Dense & 30 & 76.92 & 26 & 66.67 & 56 & 71.79 \\
\hline Total & 39 & 100 & 39 & 100 & 78 & 100 \\
\hline \multicolumn{7}{|c|}{ Drain water reservoirs } \\
\hline$>1$ month / 1 times & 13 & 33.33 & 9 & 23.08 & 22 & 28.21 \\
\hline$\leq 1$ month / 1 times & 26 & 66.67 & 30 & 76.92 & 56 & 71.79 \\
\hline Total & 39 & 100 & 39 & 100 & 78 & 100 \\
\hline \multicolumn{7}{|c|}{ Close water reservoirs } \\
\hline Not Close & 7 & 17.95 & 3 & 7.69 & 10 & 12.82 \\
\hline Close & 32 & 82.05 & 36 & 92.31 & 68 & 87.18 \\
\hline Total & 39 & 100 & 39 & 100 & 78 & 100 \\
\hline \multicolumn{7}{|l|}{ Bury thrift } \\
\hline Not Habit & 31 & 79.49 & 18 & 46.15 & 49 & 62.82 \\
\hline Habit & 8 & 20.51 & 21 & 53.85 & 29 & 37.18 \\
\hline Total & 39 & 100 & 39 & 100 & 78 & 100 \\
\hline \multicolumn{7}{|l|}{ Use insect screen } \\
\hline No & 35 & 89.74 & 30 & 76.92 & 65 & 83.33 \\
\hline Yes & 4 & 10.26 & 9 & 23.08 & 13 & 16.67 \\
\hline Total & 39 & 100 & 39 & 100 & 78 & 100 \\
\hline \multicolumn{7}{|l|}{ Hanging clothes } \\
\hline Yes & 25 & 64.10 & 13 & 33.33 & 38 & 48.72 \\
\hline No & 14 & 35.90 & 26 & 66.67 & 40 & 51.28 \\
\hline Total & 39 & 100 & 39 & 100 & 78 & 100 \\
\hline
\end{tabular}


clothes in their house was more prevalent in the case group (64.10\%), compared with the control group (33.33\%).

\subsection{Bivariate analysis}

TABLE 2: Relationships with Dependent Variables Independent Variables.

\begin{tabular}{l|c|c|c|}
\hline Variables & p value & OR & 95\% Cl \\
\hline Temperature & 0.065 & 4 & $(0.849-18.836)$ \\
\hline Humidity & 0.687 & 1.5 & $(0.25-8.977)$ \\
\hline The lighting & 0.002 & 4 & $(1.501-10.567)$ \\
\hline The Density & 0.359 & 0.636 & $(0.246-1.641)$ \\
\hline Drain water reservoirs & 0.359 & 1.571 & $(0.609-4.053)$ \\
\hline Close water reservoir & 0.179 & 3 & $(0.605-14.864)$ \\
\hline Burry Thrift & 0.002 & 5.333 & $(1.554-18.303)$ \\
\hline Use Insect screen & 0.179 & 2.25 & $(0.692-7.306)$ \\
\hline Hanging Clothes & 0.014 & 3 & $(1.190-7.557)$ \\
\hline
\end{tabular}

Table 2 shows that the test statistic to the air temperature in the house obtained $\mathrm{p}$ value $=0.065$, which means there is no significant relationship between the air temperature inside the house with the DHF prevalence. The humidity variable in the house was obtained $p$-value $=0.687$, which means there was no significant relationship between the air humidity in the house with the DHF prevalence. Variable home lighting captured p-value $=0.002$, which means there was a significant relationship between the lighting in the home with the DHF prevalence with Odd Ratio $(O R)=4$. For the variable density of dwelling obtained $p$-value $=0.359$, which means there was no significant relationship between the dwelling density with the DHF prevalence. To drain water reservoirs variable obtained $p$-value $=0.359$, which indicates there was no significant relationship between the drain landfill with the DHF prevalence. VaCovering water reservoirs obtained $p$-value $=0.179$, which means there was no significant relationship between closing the landfill by the DHF prevalence. The burying/ disposing used goods behavior obtained $p$-value $=0.002$, which means there was a significant relationship between burying/disposing used goods with the prevalence of DHF with $O R=5.33$. The use of insect-screen obtained $p$-value $=0.179$. It means that there was no significant relationship between the use of the insect-screenwith the prevalence of DHF. Hanging clothes obtained $p$-value $=0.014$, which means there was a significant relationship between the hanging clothes with the prevalence of dengue disease with $\mathrm{OR}=3$. 
TABLE 3: Dominant Variables Affecting the DHF Prevalence.

\begin{tabular}{|l|c|c|c|c|c|}
\hline Variable & OR & $\mathbf{9 5 \%} \mathbf{C l}$ & Coefficient & SE & p-value \\
\hline Temperature & 1.400 & $0.454-4.316$ & 0.337 & 0.574 & 0.557 \\
\hline The lighting & 3.347 & $1.129-9.922$ & 1.208 & 0.554 & $0.029 *$ \\
\hline Drain water reservoirs & 2.216 & $0.370-13.244$ & 0.795 & 0.912 & 0.383 \\
\hline Close water reservoir & 2.955 & $0.979-8.917$ & 1.083 & 0.563 & 0.054 \\
\hline Use Insect screen & 1.671 & $0.392-7.121$ & 0.513 & 0.739 & 0.487 \\
\hline Hanging Clothes & 2.999 & $1.048-8.582$ & 1.098 & 0.536 & 0.040 \\
\hline
\end{tabular}

\subsection{Multivariate analysis}

Table 3 shows the variables that had a significant relationship with the DHF occurrence ( $p$-value $<0.05$ ) were the house-lighting and hanging clothes behavior. The dominant risk factor affecting the prevalence of dengue at the public health of Air Dingin was the lighting within the house with a $p$-value $=0.029$ and the value of $O R=3.34$, which means people living in house with dark lighting had 3.34 times higher risk of having DHF compared to them who were not living in the dark lightning houses.

\section{Discussion}

Based on the bivariate analysis, there was no significant relationship between the air temperatures inside the house with the prevalence of DHF at Air Dingin PHC. This study is in line with research conducted by Pramudiyo et al. which stated that there was no significant relationship between air temperatures with the DHF prevalence. In addition from being influenced by the house' internal factors (improper ventilation, the dwelling density, materials and building structures), the air temperature in the house is also affected by external factors, namely the conditions geographical and topographical region (Kemenkes RI 2004). Air Dingin only consists of three villages, hence the geographical and topographical conditions are similar.

The results showed that there was no significant relationship between the air humidity in the house with DHF. The research of disease prevalence is in line with a study conducted by Trixie; et al. stated that there was no significant relationship between the humidity of the room with the incidence of dengue. (9) Moisture influenced by rainfall and the plant/tree protector, especially when plants shut. Air Dingin PHC consists of the Village Hall Tower, Village Lubuk Paducah Minturn, and Village Water is an area of cultivation of horticulture crops which are the areas of agriculture and plantation. In the research, it is known that most of the respondents (the case group and the control group) have humidity in the house is good for the development of mosquitoes that is $>$ 
$60 \%$ so that the transmission of dengue disease may occur in the homegroup or the control group cases.

The results showed that there was a significant relationship between the lighting in the home with the DHF prevalence with $O R=4$, which means people living in the dark lighting houses had four times higher risk of getting DHF than people who wer not living there.. This study is in line with the results of research conducted by Qoriatus and Ketut (2014). They found no significant relationship between exposure to the prevalence of dengue (Sholihah and Prasetyo 2014). The intensity of the house lighting is an important factor that affects the mosquitoes' flying activity of and rest. Aedes aegypti mosquitoes like to fly and rest in a dark and damp that is inside the house, including in the bedroom, bathroom, and kitchen. Low lighting and high humidity are favorable conditions for mosquitoes (WHO 2004). Dark lighting houses are preferably for mosquito and potential as breeding location for mosquitoes. The possibility of DHF transmission is higher in dark lighting houses than ligher lightning houses.

The results showed that there was no significant correlation between the dwelling density with the prevalence of DHF. This study is in line with the results of research conducted by Sofia, et al. who showed that there was no correlation between population density in the house with the DHF prevalence (Sofia et al. 2014). Aedes aegypti habituallybites several people repeatedly in a short time that causes dengue virus moves to multiple people at once, hence some people with DHF was often reported in one house (Sunaryo and Soedarmo 2009).

The results showed that there was no significant correlation between the landfill drain with the DHF prevalence. This study is in line with research conducted by Deni (2012) which reported that there was no significant relationship between the practice of draining the water tank with the prevalence of dengue (Rahman 2012). Draining water reservoir areas need to be done regularly at least once a week so that mosquitoes cannot breed inside. It needs \pm 9-10 days for Aedes mosquitoss' egg to be adult mosquitos. Draining water reservoir once a week aims to break the mosquitoes' life cycle before it became an adult (Kemenkes RI 2011). From the research, showed that draining water reservoirs behavior between control and case group had equally good means.

The results showed that there was no significant relationship between closing the landfill by the prevalence of DHF. This study is in line with research conducted by Berdian et al. (2013) which states that there was no relation between covering water reservoirs behavior to the DHF prevalence (Tamza et al. 2013). Aedes aegypti female mosquitoes lay their eggs above the water surface like the inner walls of the place water reservoirs. The water must be clear and protected from direct sunlight. The place selected water is the water reservoirs in and near the home. Water reservoirs are sealed to prevent 
mosquitoes from laying their eggs and nest in it. At first, people often collect and store water for drinking, but nowadays people use galloned drinking water that can be drunk directly without boiling it first,that makes shelter and water storage in the community has reduced.

The results showed that there was a significant relationship between waste products' burying/ disposing behavior with the prevalence of DHF and OR $=5.33$, which means that the the failure of conducting this behavior will result in 5.33 times higher risk of getting DHF compared with to the ones with ones who had no waste products' burying/ disposing behavior. This study is in line with research conducted by the Winarsih (2013) which states that there was a relationship between secondhand goods buried with the prevalence of Dengue Fever (Winarsih 2013). Aedes larvae can live in clear water and rainwater (Sunaryo and Soedarmo 2009). Secondhand goods that littered are the potential mosquitos breeding location.

The results showed that there was no significant correlation between the uses of the insect screen with the prevalence of DHF. This study is in line with the results of research conducted by Kautsario. He stated that there was no relationship between the installations of the insect-screen with the prevalence of dengue (Pratama 2014). Aedes aegypti females have two bite activity periods, first in the morning for a few hours after sunrise and in the afternoon for a few hours before dark (WHO 2004). Insect-screen is usually only installed on home ventilation that causes the mosquitos could still enter the open places within the house.

The results showed a significant relationship between the hanging clothes behavior with the DHF prevalence with $\mathrm{OR}=3$, which means people who habitually hanging their clothes had three times higher risk of getting DHF than people who had not habitually hanging their clothes. This study is in line with Pramudiyo, et al. research. They found that there was no correlation between the habit of hanging clothes with the prevalence of dengue (Sucipto et al. 2015). According to the results of research in Panama as quoted by Widjana (2003), that there are four types of surfaces like as the resting place of mosquitoes that surface cement, wood, clothing, and metal. Male mosquitos are more often found resting on a metal surface, while the female mosquitos are more common on the surface of the forest and clothing (Suyasa et al. 2008).

The results of logistic regression analysis showed that the dominant variable affecting prevalence of dengue at the public health of Air Dingin was the house lighting with OR = 3.34, which means that the houses with dark lighting had 3.34 times higher risk of getting DHF compared to houses with lighter lighting. This study is in line with research conducted by Tri Yunis et al. in District Cimanggis Depok on late model multivariate analysis known that the most dominant environmental factors affect the prevalence of 
this disease is exposure with $\mathrm{OR}=1.40$. A healthy home requires sufficient lighting. The lack of lighting inside the house, especially sunlight is an excellent place to live and breeding of germs and disease vectors. Houses with low lighting and high humidity provide perfect conditions for mosquitoes to fly and rest.

\section{Conclusions}

The results of statistical tests concluded that there was a significant relationship between the lighting in the home, burying/disposing of waste products behavior, and hanging clothes habit with the prevalence of DHF. The dominant factor affecting the prevalence of dengue at the Air Dingin PHC is the lighting iwithin the house. People who were living in houses with dark lighting had 3.34 times higher risk of getting DHF compared with those who were living in houses with sufficient lighting.

\section{Acknowledgments}

The researchers want to express their sincere grattitude to the Air Dingin PHC, public health office of Padang, West Sumatra, and Faculty of Public Health, Andalas University.

\section{References}

[1] Dinkes. Profil Kesehatan Kota Padang Tahun 2013. Padang: Dinas Kesehatan Kota Padang, 2014.

[2] Kemenkes. 2004. Tata Laksana Demam Berdarah Dengue di Indonesia. Jakarta: Dirjen P2PL Kemenkes RI.

[3] Kemenkes. 2010. Buletin Jendela Epidemiologi Demam Berdarah Dengue. Jakarta: Pusat Data dan Surveilans Epidemiologi Kemenkes RI.

[4] Kemenkes. 2011. Modul Pengendalian Demam Berdarah Dengue. Jakarta: Dirjen P2PL Kemenkes RI.

[5] Kemenkes. 2012. Peraturan Menteri Kesehatan RI Nomor 035 Tahun 2012 tentang Pedoman Identifikasi Faktor Risiko Kesehatan Akibat Perubahan Iklim: Kementerian Kesehatan Republik Indonesia.

[6] Pratama K. 2014. Faktor Risiko Lingkungan dan Pemberantasan Sarang Nyamuk (PSN) Pada Kejadian DBD di Wilayah Kerja Puskesmas Lubuk Basung Kabupeten Agam Tahun 2013. Padang: Universitas Andalas. 
[7] Rahman DA. 2012. Hubungan Kondisi Lingkungan Rumah dan Praktik 3M dengan Kejadian DBD di Wilayah Kerja Puskesmas Blora Kabupaten Blora. Jurnal Universitas Negeri Semarang. 1:1-7.

[8] Sholihah Q, Prasetyo K. 2014. Hubungan kondisi sanitasi lingkungan, pengetahuan, dan tingkat pendidikan terhadap kejadian DBD di Kelurahan Kecamatan Sambikereb Kota Surabaya. Jurnal Universitas Negeri Semarang. 219-28.

[9] Sofia, Suhartono, Wahyuningsih NE. 2014. Hubungan Kondisi Lingkungan Rumah dan Perilaku Keluarga dengan Kejadian DBD di Kabupaten Aceh Besar. Jurnal Kesehatan Lingkungan Indonesia. 13:30-7.

[10] Sucipto PT, Raharjo M, Nurjazuli. 2015. Faktor-Faktor yang Mempengaruhi Kejadian Penyakit DBD dan Jenis Serotipe Virus Dengue di Kabupaten Serang. Jurnal Kesehatan Lingkungan Indonesia. 14 No.2:51-6.

[11] Sumantri A. 2010. Kesehatan Lingkungan (Edisi Revisi). Jakarta: Kencana, Prenada Media Group.

[12] Sunaryo S, Soedarmo P. 2009. Demam Berdarah (Dengue) Pada Anak. Universitas Indonesia: Jakarta.

[13] Suyasa ING, Putra NA, Aryanta IWR. 2008. Hubungan Faktor Lingkungan dan Perilaku Masyarakat dengan Keberadaan Vektor DBD di Wilayah Kerja Puskesmas I Denpasar Selatan. Ectrophic. 3:1-6.

[14] Tamza RB, Dharminto, Suhartono. 2013. Hubungan Faktor Lingkungan dan Perilaku dengan Kejadian DBD di Wilayah Kelurahan Perumnas Way Halim Kota Bandar Lampung. Jurnal Kesehatan Masyarakat. 2 Nomor 2.

[15] WHO. 2004. Panduan Lengkap WHO, Pencegahan dan Pengendalian Dengue dan Demam Berdarah Dengue. Jakarta: Kedokteran EGC.

[16] Widiyastuti N. Analisis faktor lingkungan dan praktik keluarga dalam PSN terhadap kejadian DBD di Kota Semarang. Semarang: Universitas Negeri Semarang; 2011.

[17] Winarsih S. 2013. Hubungan Kondisi Lingkungan Rumah dan Perilaku PSN dengan Kejadian DBD. Jurnal Universitas Negeri Semarang. 1-9. 